\title{
Role of uterine immune cells in early pregnancy in pigs
}

\author{
H. Engelhardt ${ }^{1}$, B. A. Croy ${ }^{2}$ and G. J. King ${ }^{1}$ \\ Departments of ${ }^{1}$ Animal and Poultry Science and ${ }^{2}$ Biomedical Sciences, University of Guelph, \\ Guelph, Ontario, Canada N1G 2W1
}

The immune system discriminates 'self' from 'non-self', and eliminates that which it determines to be non-self. Mammalian pregnancy appears to represent a failure of self-non-self discrimination, yet it is a highly successful reproductive strategy. We present evidence that the immune system of the female pig responds to the challenges of both mating and the presence of conceptuses. Mating induces an influx of inflammatory leukocytes into the endometrial stroma and uterine lumen. This response, while partially under endocrine control, is amplified by as yet unidentified factors in seminal plasma. In addition to preventing microbial infection, this mating-induced immune response may enhance reproductive performance. During the first month of pregnancy when intimate contact between maternal and fetal tissues is being established, the number of uterine lymphocytes decrease in the luminal epithelium and increase in the endometrial stroma at sites of conceptus attachment. The majority of these lymphocytes express the CD2 and CD8 surface markers, consistent with either T or natural killer (NK) cell lineage. Dispersed endometrial cells obtained during early gestation exhibit a pregnancy-specific increase in NK-like lytic activity. Our ongoing efforts to determine whether these NK-like lymphocytes are the ones that localize to sites of conceptus attachment are discussed. We speculate on how the reactions of pig uterine leukocytes to seminal plasma and conceptuses might contribute to successful pregnancy.

\section{Introduction}

Immunology is commonly thought of as the highly complex interactions between cells and molecules that mediate the recognition and elimination of potential pathogens. However, virtually all functions of the immune system can be related to its ability to distinguish 'self' from 'non-self' and to eliminate or otherwise inactivate that which it determines to be non-self. Pregnancy appears to represent a failure of self-non-self discrimination. At mating, the female is exposed to spermatozoa and male-derived proteins in semen. Throughout gestation, she is exposed to the conceptus, which is non-self by virtue of its expression of developmentally regulated, unique embryonic antigens and paternally inherited antigens. Yet mammalian pregnancy is a proven, highly successful reproductive strategy.

Most hypotheses about the role of uterine leukocytes in pregnancy are based on investigations conducted in rodents and humans. In these species, implantation is associated with degeneration of the uterine epithelial layer and invasion of the endometrial stroma. There is direct contact between circulating maternal blood and the trophoblast. In contrast, the placentae of conventional livestock species are characterized by little or no invasion of maternal tissues and no direct contact between maternal and fetal blood. The pig exemplifies the least intimate form of placentation. The uterine epithelium remains intact throughout gestation, invasion is completely prevented and the relationship between maternal and fetal tissues is more appropriately described as 'attachment' rather than 'implantation' (reviewed by King, 1993). The ultimate placental union consists of interlocking microvilli of chorionic and uterine epithelia which begin to form by day 12 or 13 (Keys 
and King, 1990). By day 30 (term = 114 days), attachment extends over the entire surface of the maternal-fetal interface except at gland openings and the extreme ends of the chorion.

In the haemochorial placenta of rodents and humans, the presence of specialized subsets of immune cells or leukocytes within the pregnant uterus and the activation of these cells by pregnancy are emerging themes (Croy et al., 1997a). The fact that the relationship between maternal and fetal tissues in the epitheliochorial placenta of the pig is so superficial raises the question of whether the pig uses similar strategies for coping with the immunological challenges of pregnancy. In this review, we first provide a brief overview of the immune system with emphasis on immune cells likely to be present in the uterine mucosa. We then present evidence that uterine leukocytes in sows do indeed respond to the challenges of both mating and contact with conceptuses and we consider how these responses might contribute to successful pregnancy.

\section{The Immune System: An Overview}

\section{Functional divisions of the immune system}

Immune responses can be classified as either antigen specific or innate. The latter responses are also called natural immunity. Natural immune mechanisms are generally effective without prior exposure to the antigen and are available at very short notice. Antigen-specific or acquired immunity requires prior experience, is specific for the stimulating antigen, and develops over several days. The effector cells in natural immunity are phagocytes (macrophages and neutrophils) and natural killer (NK) lymphocytes. The important cell types in antigen-specific immunity are B and T lymphocytes, and antigen-presenting cells (macrophages and dendritic cells). These divisions of immune responses are largely a matter of convenience. In reality, antigen specific and innate immune mechanisms are inextricably linked with one another.

\section{Morphology and function of the major leukocyte classes}

Granulocytes. Granulocytes, named for their abundant cytoplasmic granules, are the most numerous leukocytes in peripheral blood. These leukocytes, often referred to as inflammatory cells, play important roles in both natural and specific immunity. Neutrophils, also known as polymorphonuclear leukocytes or polymorphs because of their distinctive multilobed, morphologically diverse nuclei, are the predominant circulating granulocyte. Neutrophils respond rapidly to chemotactic stimuli and are the major cell population in acute inflammatory responses.

Lymphocytes. The next most abundant circulating leukocytes are lymphocytes (B, T and NK cells), which are typically small- to medium-sized cells with large nuclei surrounded by a thin rim of cytoplasm. Their relatively nondescript appearance contrasts with remarkable functional diversity. B lymphocytes are the only cells capable of producing antibodies. In mammals, the early stages of B-cell maturation occur in the bone marrow. Differentiation into specialized forms called plasma cells, found only in lymphoid organs or at sites of immune responses, is the final fate of a B cell.

The second major class of lymphocytes is the $T$ cells. They originate from precursors in the bone marrow and migrate to the thymus for final maturation. $T$ cells are further subdivided into several functionally distinct subpopulations, the best defined of which are helper $\left(T_{H}\right)$ cells and cytotoxic $\left(\mathrm{T}_{\mathrm{C}}\right)$ cells. In response to antigenic stimulation, $\mathrm{T}_{\mathrm{H}}$ cells release cytokines which promote the proliferation and differentiation of other $T$ cells, $B$ cells, NK cells and macrophages. $T_{C}$ cells lyse cells that express non-self antigens such as cells infected by viruses. 'Suppressor' $T$ cells that inhibit immune responses may also exist. However, there is considerable controversy over whether suppression is mediated by a distinct $T$-cell subset, or by $T_{C}$ or $T_{H}$ cells under certain conditions. The only structures that $T_{H}$ and $T_{C}$ cells recognize are peptide antigens attached to proteins that are encoded in the major histocompatibility complex (MHC) and expressed on the surfaces of other cells 
(Abbas et al., 1994). There are two different types of MHC gene products, called MHC class I and class II molecules. While $T_{C}$ cells recognize non-self peptides attached to class I MHC molecules, $T_{H}$ cells recognize only those peptides associated with class II molecules. In general, class I molecules are present on virtually all nucleated cells, whereas class II molecules are normally expressed only on B cells, antigen-presenting cells and endothelial cells.

The third major class of lymphocyte does not express markers for either $\mathrm{T}$ or $\mathrm{B}$ cells, and was therefore initially called the null cell population. In humans and mice, most null cells are relatively large lymphocytes with numerous cytoplasmic granules that are capable of spontaneous lysis of a variety of tumour cells and virally infected cells. This lymphocyte population is now known as NK cells. There is mounting evidence that uterine leukocytes of this lineage play important roles in pregnancy in humans and rodents (reviews: Croy et al., 1996; Head, 1996; King et al., 1996).

Mononuclear phagocytes. These cells originate from a common precursor in the bone marrow and, after maturation and subsequent activation, achieve varied morphological forms. Monocytes, large cells with characteristic horseshoe-shaped nuclei, are immature forms that enter the blood from the bone marrow. Once they settle in tissues, these cells mature and become macrophages, which can in turn be activated and assume different forms. Macrophages are central for both specific and natural immunity. They are the principal scavenger cells of the body and recruit other inflammatory cells by secretion of cytokines. In specific immunity, macrophages function as accessory or antigenpresenting cells by presenting foreign antigens to $\mathrm{T}$ cells in association with MHC molecules. Dendritic cells, identified morphologically by their spine-like projections, are thought to be related in lineage to mononuclear phagocytes. They are found in the interstitial tissue of most organs, scattered through the epidermis of the skin, and in T cell-rich areas of lymph nodes and spleen.

\section{The CD nomenclature for leukocytes}

Although lymphocytes are relatively homogeneous by light microscopy, functionally distinct populations have been found to express different membrane proteins. A uniform nomenclature has been adopted in which a cell-surface marker identifying a particular lineage or differentiation stage that has a defined structure and is recognized by a group ('cluster') of monoclonal antibodies is designated a 'CD' or 'cluster of differentiation', followed by a number indicating its order of discovery. Many of these phenotypic markers have been found to play important roles in the function of these cells. For example, all $\mathrm{T}$ cells express $\mathrm{CD} 3$, which refers to a group of proteins that form part of the T-cell receptor complex. $T_{H}$ cells express CD4, while $T_{C}$ cells express a different marker called CD8. The surface phenotype of these $\mathrm{T}$-cell subsets would thus be designated $\mathrm{CD}^{+}{ }^{+} \mathrm{CD} 4{ }^{+} \mathrm{CD}^{-}$and $\mathrm{CD} 3{ }^{+} \mathrm{CD} 4{ }^{-} \mathrm{CD} 8^{+}$, respectively.

Although this nomenclature was originally developed for humans, it is now common practice to refer to homologous markers in other species by the same CD designation. The expression of selected $\mathrm{CD}$ molecules by pig leukocytes is shown in Table 1 . In both species, the T-cell receptor, which is composed of two covalently linked glycoprotein chains, exists as an $\alpha \beta$ dimer or a $\gamma \delta$ dimer. In humans, the CD8 antigen also has two different forms: an $\alpha \beta$ heterodimer and $\alpha \alpha$ homodimer (Moebius $e t$ al., 1991). Lymphocytes expressing the $\alpha \alpha$ dimer have been found to be enriched at mucosal surfaces such as the gut (Guy-Grand et al., 1991). When detected using an antibody that recognizes both forms, cellsurface expression of the $\alpha \beta$ dimer is high (CD8 $8^{\text {bright }}$ ) and that of the $\alpha \alpha$ dimer low (CD8 $\left.{ }^{\text {dim }}\right)$. It appears that two different forms of CD8 also exist in the pig, in that there are CD8 $8^{\text {right }}$ and CD8 $8^{\mathrm{dim}}$ lymphocytes. As in the human, $T_{C}$ cells in the pig are $C D 4-C D 8^{\text {bright }}, T_{H}$ cells are $C D 4^{+} C D 8^{-}$, and double positive $T$ cells are CD4 ${ }^{+} C D 8^{\mathrm{dim}}$ (Pescovitz et al., 1985; Yang and Parkhouse, 1996). In the human circulation, virtually all $T$ cells fall into either $T_{H}$ or $T_{C}$ categories and $\gamma \delta$, double positive and double negative $T$ cells are rare. In pigs, in contrast, $\gamma \delta \mathrm{T}$ cells with a CD4-CD8 ${ }^{-}$phenotype and $\mathrm{CD} 4^{+} \mathrm{CD} 8^{+} \alpha \beta \mathrm{T}$ cells constitute major circulating populations (Binns, 1982; Pescovitz et al., 1985; Saalmüller et al., 1987; Saalmüller et al., 1990; Hirt et al., 1990; Yang and Parkhouse, 1996). As in humans, NK cells in pigs are CD2 ${ }^{+}$CD4-CD8 ${ }^{\text {dim }}$ (Pescovitz et al., 1988; Yang and Parkhouse, 1996). 
Table 1. Expression of selected CD molecules by pig leukocytes

\begin{tabular}{|c|c|c|c|c|c|c|c|c|}
\hline \multirow[b]{4}{*}{ Marker } & \multicolumn{7}{|c|}{ Antigen distribution } & \multirow{4}{*}{$\begin{array}{l}\text { Known or proposed } \\
\text { function }\end{array}$} \\
\hline & \multicolumn{5}{|c|}{ Lymphocytes } & \multirow[b]{3}{*}{ Gran } & \multirow[b]{3}{*}{$\mathrm{M} \phi$} & \\
\hline & \multicolumn{2}{|c|}{$\alpha \beta \mathrm{T}$} & \multirow[b]{2}{*}{$\gamma \delta \mathrm{T}$} & \multirow[b]{2}{*}{ NK } & \multirow[b]{2}{*}{ B } & & & \\
\hline & $\mathrm{T}_{\mathrm{H}}$ & $\mathrm{T}_{\mathrm{c}}$ & & & & & & \\
\hline $\mathrm{CD} 2$ & + & + & - & + & $\because$ & - & - & $\begin{array}{l}\text { Adhesion, T-cell } \\
\text { activation }\end{array}$ \\
\hline $\mathrm{CD} 3$ & + & + & + & - & - & - & - & $\begin{array}{l}\text { Signal transduction } \\
\text { (component of T-cell } \\
\text { receptor) }\end{array}$ \\
\hline CD4 & + & - & - & - & - & - & - & $\begin{array}{l}\text { Adhesion (binds to class } \\
\text { Il } \mathrm{MHC} \text { ), signal } \\
\text { transduction }\end{array}$ \\
\hline CD8 & - & + & - & + & - & 1 & - & $\begin{array}{l}\text { Adhesion (binds to class } \\
\text { I MHC), signal } \\
\text { transduction }\end{array}$ \\
\hline CD16 & - & - & - & + & - & + & + & $\begin{array}{l}\text { Low affinity } \mathrm{FC \gamma} \\
\text { receptor, activation of } \\
\text { NK cells }\end{array}$ \\
\hline $\mathrm{CD} 44$ & + & + & + & + & + & + & + & Adhesion \\
\hline CD45 & + & + & + & + & + & + & + & $\begin{array}{l}\text { Signal transduction } \\
\text { (leukocyte common } \\
\text { antigen) }\end{array}$ \\
\hline
\end{tabular}

$\alpha \beta$ and $\gamma \delta$ : expressing those variants of the T-cell receptor, respectively; $T_{H}$ and $T_{c}$ : helper and cytotoxic $T$ cells, respectively; NK: natural killer cells; gran: granulocytes; $M \phi$ : cells of monocyte/macrophage lineage.

\section{The uterus is a component of the mucosal immune system -}

The immune system can also be classified anatomically. Leukocytes in the peripheral blood, bone marrow, spleen, thymus, lymph nodes, liver and thoracic duct constitute the systemic immune system. In many textbooks, aggregates of lymphoid cells in the gastrointestinal and respiratory tracts are presented as the mucosal immune system (Abbas et al., 1994). However, both male and female reproductive tràcts belong in the mucosal category. A study in mice showing that intravenously injected cells from the mesenteric lymph node migrated to the female reproductive tract along with several other mucosal surfaces (McDermott and Bienenstock, 1979) provided evidence that the uterus is a member of a common mucosal immune system. Mucosal surfaces comprise an epithelium resting on a basement membrane supported by a layer of connective tissue. Because the uterine epithelium is maintained throughout gestation in pigs, the pig uterus retains the structural arrangement of a mucosal surface even in pregnancy. In addition to the mechanisms that normally regulate immune cell function, uterine leukocyte populations are likely to be under endocrine regulation. Oestradiol treatment stimuiates the appearance of IgA-positive cells in the rat uterus (Wira $e t$ al., 1980) and increases the tissue content of IgA (Wira et al., 1980, 1983). Migration of mesenteric lymph node cells to the female reproductive tract of mice is greater at pro-oestrus and oestrus than at met- and dioestrus, while migration to the small intestine is unchanged (McDermott et al., 1980). In spite of these differences, leukocyte populations of the uterus face challenges similar to those encountered at other mucosal surfaces. Within the gastrointestinal tract, a protective local response against viruses, bacteria and other hazardous agents is necessary but local and systemic antigen-specific tolerance to nutritional components is also required. Similarly, the uterus must be able to eliminate infectious 


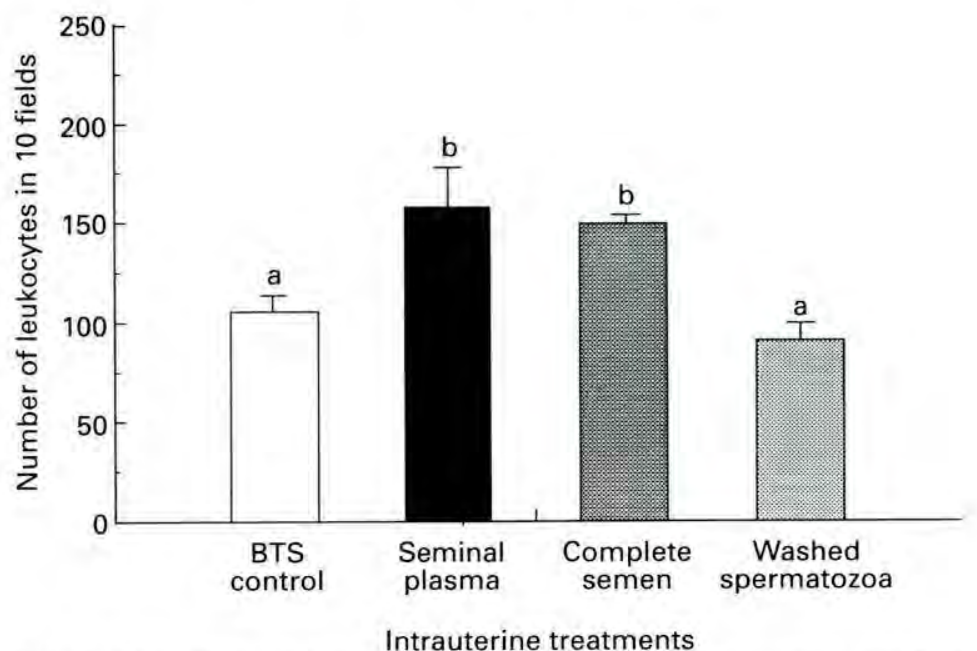

Fig. 1. The effect of intrauterine infusion of complete semen, washed spermatozoa, seminal plasma or semen extender (Beltsville Thawing Solution; BTS) at oestrus on the number of endometrial leukocytes. Uteri were obtained at slaughter on the morning after insemination (approximately $18 \mathrm{~h}$ after treatment). In this preliminary trial, leukocytes were identified by their morphology in sections stained with haematoxylin and eosin. Numbers of leukocytes in epithelial and stromal compartments were pooled within animal. Bars with different letters are significantly different $(P<0.05)$.

agents while coping with the introduction of potentially antigenic male factors at mating and intimate contact with the genetically disparate conceptus throughout pregnancy.

\section{The Maternal Immune Response to Mating}

The pig is an excellent animal for investigating the immunological effects of semen on the uterus, because mating involves the deposition of large volumes (up to $500 \mathrm{ml}$ ) of semen directly into the uterine lumen. Semen consists of mature spermatozoa suspended in seminal plasma, which is composed of the combined secretions of the male accessory sex glands. The major accessory sex glands in the boar are the bulbourethral glands which are the source of the gel fraction of the ejaculate, and the seminal vesicles, which contribute the bulk of the fluid. In natural mating, approximately one third of the ejaculate is lost via backflow through the cervix (Viring and Einarsson, 1981). Of the remainder, most is absorbed by the uterine mucosa within $5 \mathrm{~h}$ (du Mesnil du Buisson and Dauzier, 1955). Spermatozoa reach the oviduct within $15 \mathrm{~min}$ after mating (Burger, 1952). When added to in vitro tests of immune function, seminal plasma in species studied so far has been shown to inhibit activities of most immune cell types, including T cells, B cells, NK cells, macrophages and neutrophils (reviews: Alexander and Anderson, 1987; Thaler, 1989). However, these findings may not reflect events occurring within the female reproductive tract.

\section{The leukocytic response to seminal plasma}

Mating in pigs is associated with a rapid influx of inflammatory leukocytes (neutrophils and macrophages) into the endometrial stroma and uterine lumen (Lovell and Getty, 1968). In agreement with Hadjisavas et al. (1994), we found that infusion of either seminal plasma or complete semen into the uterine lumen was equally effective in eliciting an influx of leukocytes into the endometrium 
(a)

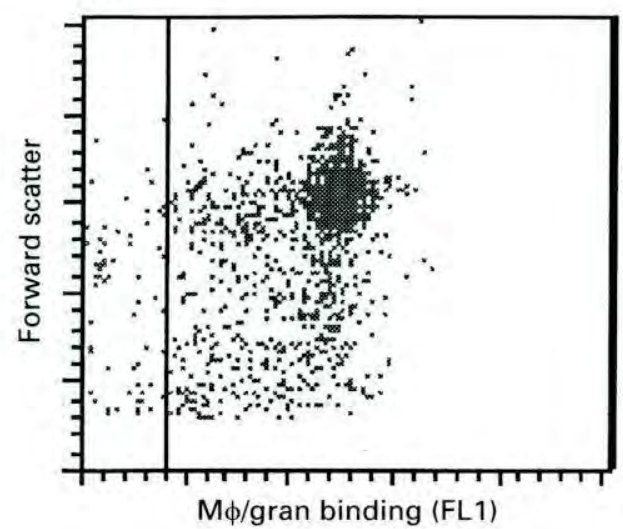

(c)

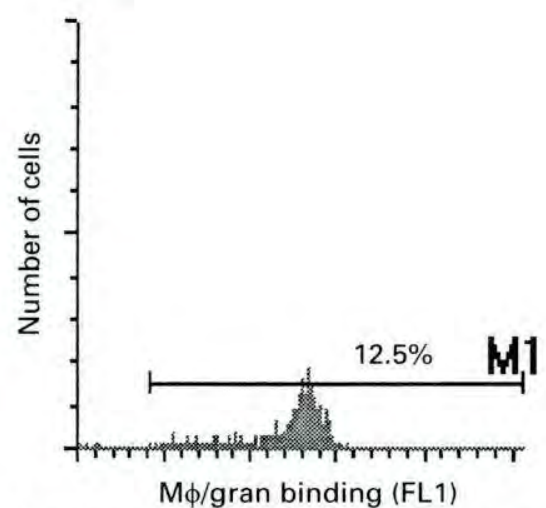

(b)

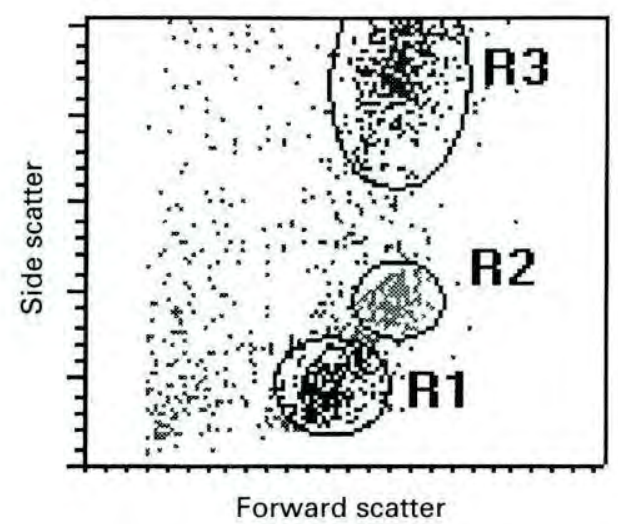

(d)

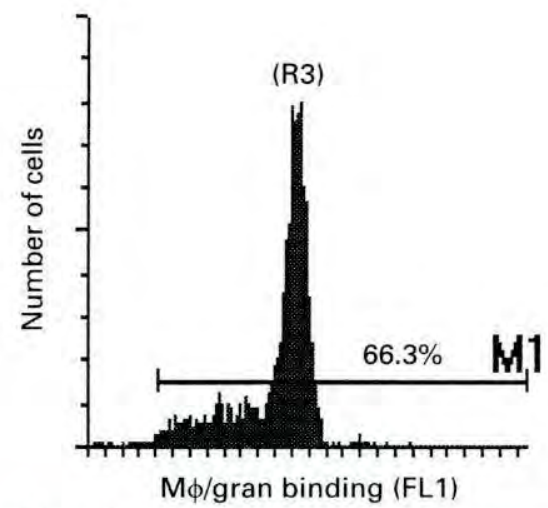

Fig. 2. Flow cytometric characterization of cells flushed from the uterine lumen of a gilt receiving an intrauterine infusion of seminal plasma at oestrus. The uterus was obtained at slaughter approximately $18 \mathrm{~h}$ after treatment. Cells were incubated with 74-22-15, an antibody reactive with macrophages (M $\phi)$ and granulocytes, followed by a goat anti-mouse secondary antibody coupled to fluorescein isothiocyanate (FITC; detected in FL1). The scatter plot (a) (FL1 versus forward scatter) shows the total number of positive cells. Scatter characteristics (forward scatter $\sim$ cell size; side scatter $\sim$ cell granularity) were used to gate on lymphocytes, $\mathrm{M} \phi$ and granulocytes (R1, R2 and R3, respectively; (b)). The histograms indicate the proportion of (c) M $\phi$ and (d) granulocytes binding to the primary antibody.

(Fig. 1; Engelhardt et al., 1996), indicating that the active factor was associated with seminal plasma rather than spermatozoa. The number of endometrial leukocytes in gilts infused with washed spermatozoa was not different from that of controls infused with a semen extender (Beltsville Thawing Solution (BTS) without antibiotics).

The luminal infiltrate consists primarily of either neutrophils ( $30 \mathrm{~min}$ to $27 \mathrm{~h}$ after mating; Lovell and Getty, 1968) or macrophages (9-10 h after mating; Hadjisavas et al., 1994). In our flow cytometric study, granulocytes and macrophages were distinguished from other leukocyte types by binding to a granulocyte-macrophage marker and from each other by scatter characteristics. Neutrophils were the predominant cell type in luminal flushings collected approximately $18 \mathrm{~h}$ after exposure to seminal plasma (Fig. 2). Assessment of binding to a pan leukocyte marker (plots not shown) indicated that (i) the cells with the scatter characteristics of lymphocytes (R1 in Fig. 2) were not leukocytes and (ii) granulocytes and macrophages accounted for nearly all the leukocytes in the 


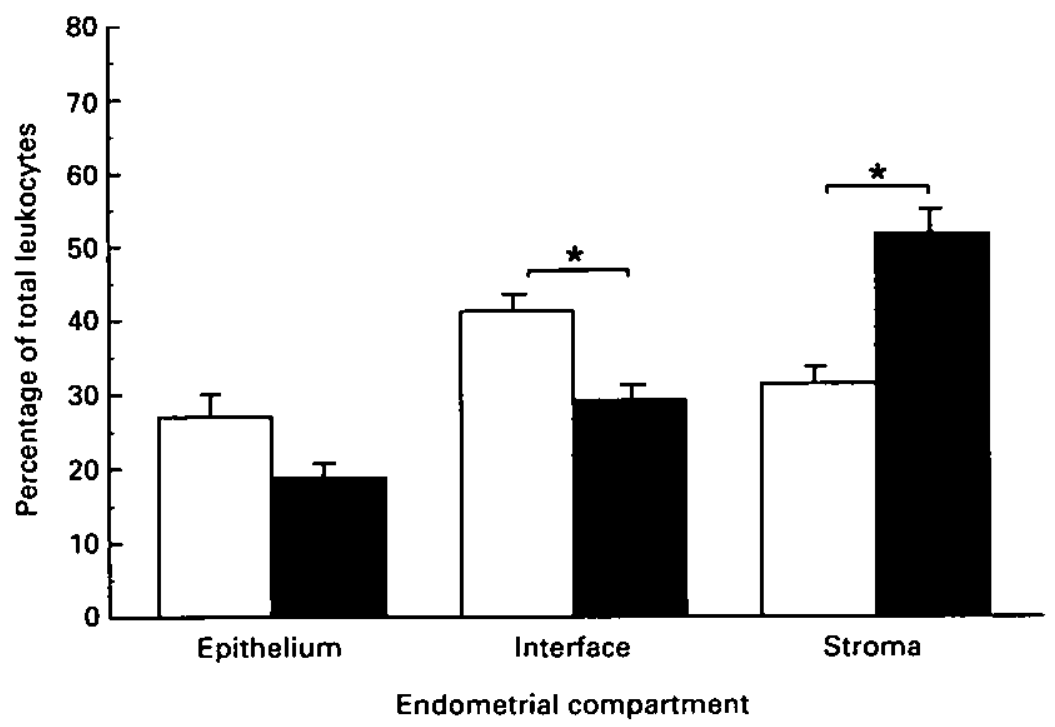

Fig. 3. The effect of stage of cycle on the distribution of leukocytes within endometrial tissue. Uteri were obtained at slaughter on the morning after insemination (approximately $18 \mathrm{~h}$ after treatment) at $(\mathbf{D})$ oestrus $(n=9)$ or $(\square)$ dioestrus (day $10-12 ; n=6$ ). Leukocytes were identified in uterine tissue by binding to a pan leukocyte marker (CD44). Positive cells located immediately beneath the luminal epithelium were considered to be in a third endometrial compartment-called 'interface'. Data are expressed as percentage of total leukocytes within each animal. Because intrauterine treatments (semen extender control versus seminal plasma) had no significant effect on leukocyte distribution $(P>0.05)$, data for these treatments were pooled. "Pairs of bars are significantly different $(P>0.05)$

luminal infiltrate. In inflammatory responses to injury or infection, neutrophils are the first phagocytes on the scene, arriving within 30-60 min (Abbas et al., 1994). If the cause of the response persists, the area will be infiltrated by macrophages and lymphocytes within $5-6 \mathrm{~h}$. The fact that lymphocytes were not present in luminal flushings collected $18 \mathrm{~h}$ after exposure to seminal plasma suggests that the leukocytic response to mating differs from a conventional inflammatory response.

\section{Endocrine influences on the response to seminal plasma}

To assess the influence of endocrine status on the ability of seminal plasma to alter endometrial leukocyte distribution, we compared the proportion of leukocytes in epithelial and stromal compartments of the endometrium in gilts receiving intrauterine infusions of seminal plasma at either oestrus or dioestrus (days 10-12). Control gilts at each stage were infused with the same volume of BTS. Leukocytes were identified in paraffin wax embedded tissue using the then available pig pan leukocyte marker (BAT31A; VMRD Inc., Pullman, WA). This antibody has subsequently been identified as an antiCD44 antibody which binds to $100 \%$ of pig peripheral blood leukocytes (Zuckerman et al., 1994). In gilts infused with both BTS and seminal plasma, large numbers of leukocytes congregated at the epithelial-stromal interface, particularly in oestrous animals. Because of the difficulty in determining their position relative to the basement membrane, leukocytes located immediately beneath the luminal epithelium were considered to be in a third endometrial compartment called the 'interface'. The proportion of leukocytes located in epithelial, interface and stromal compartments was not influenced by intrauterine treatment $(P>0.05 ; \mathrm{Fig} .3)$. However, stage of cycle affected distribution among these compartments: oestrous gilts had a greater proportion of endometrial leukocytes at the interface and a 


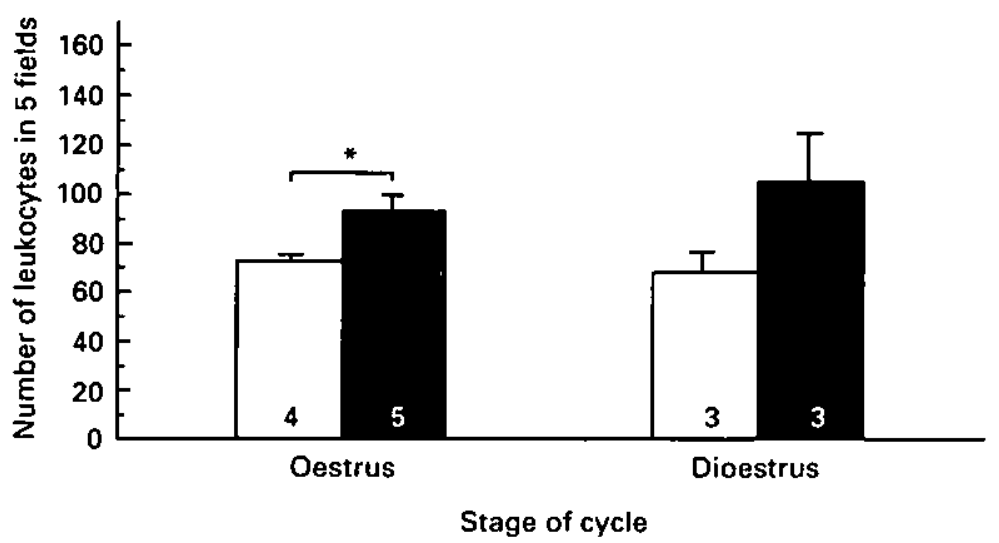

Fig. 4. The effect of intrauterine infusion of ( $\square$ ) seminal plasma or ( $\square$ ) semen extender (Beltsville Thawing Solution; BTS) at oestrus versus dioestrus on the number of endometrial leukocytes. Uteri were obtained at slaughter on the morning after insemination (approximately $18 \mathrm{~h}$ after treatment). Leukocytes were identified in uterine tissue by binding to a pan leukocyte marker (CD44). Numbers of leukocytes in epithelial and stromal compartments were pooled within animal. Numbers within bars indicate numbers of animals. Infusion of seminal plasma resulted in a greater number of endometrial leukocytes relative to controls receiving BTS semen extender. This effect was significant $(P<0.05)$ at oestrus but not at dioestrus..

correspondingly lower proportion within the stroma compared with dioestrous gilts $(P<0.01 ;$ Fig. 3$)$. The fact that stage of cycle strongly influenced uterine leukocyte distribution was consistent with earlier reports describing the infiltration of large numbers of neutrophils into the uterus at oestrus in both unmated and mated pigs (Corner, 1921; Bischof et al., 1994).

Although the shift in leukocyte distribution among endometrial compartments appears to be a response to the endocrine milieu at oestrus, seminal plasma does influence the magnitude of the leukocytic response. The total number of endometrial leukocytes $18-20 \mathrm{~h}$ after intrauterine infusion of BTS (control) and seminal plasma at oestrus and dioestrus are shown (Fig. 4). Seminal plasma infusion increased the number of endometrial leukocytes at both stages of the cycle, although this effect was not significant in dioestrous gilts $(P>0.05)$. It must be noted that responses in dioestrous gilts were more variable, probably because a large proportion of these animals developed pyometra in response to treatment. Pyometra (identified by cloudiness of fluid flushed from the uterine lumen) was never observed in gilts infused at oestrus or in three dioestrous gilts killed without treatment. This observation is discussed below.

\section{Contribution of the leukocytic response to successful pregnancy}

Prevention of microbial infection. Both the endocrine and seminal plasma-mediated aspects of the leukocytic response to mating may be important in containing the inevitable microbial contamination introduced into the uterus by insemination. The potential importance of this antimicrobial effect should not be underestimated, particularly with respect to the preparation of semen for artificial insemination (AI). Scofield et al. (1974) assessed uterine bacterial flora and early embryonic loss rates in gilts 9 and 13 days after natural mating. Of the 50 pigs examined, $46 \%$ showed growth on culture. In the study of Scofield $e t$ al. (1974), although uterine bacterial flora were compatible with pregnancy, early embryonic losses were higher in pigs with infected versus uninfected uteri (sterile: $37.5 \%$; infected: $69.4 \%$; assessed at day 13). Assuming that at least five embryos are necessary for the maintenance of pregnancy in pigs (Polge et al., 1966), four of the six pigs with infected uteri at day 13 in that study would have been expected to return to service, compared with only one of the seven gilts with no infection. 
In cattle, it has long been known that resistance to uterine infection is greatest at oestrus and lowest during dioestrus (Black et al., 1953). That this difference was related to circulating oestrogen and progesterone concentrations was demonstrated by Rowson et al. (1953), who showed that insemination of luteal phase or ovariectomized, progesterone-treated cows almost invariably resulted in pyometritis, while oestrous or ovariectomized, oestrogen-treated cows were remarkably resistant to infection even using semen known to be microbially contaminated. Addition of antibiotics to semen, which is standard practice in $\mathrm{AI}$ in livestock, prevented infection in luteal phase animals.

Both progesterone-mediated immunosuppression and oestrogen-mediated increases in resistance could contribute to the cycle-related differences in susceptibility. Oestrogen could increase resistance through its ability to increase blood flow, vascular permeability and uterine motility. In experimentally infected rabbits, ligation of the uterus at oestrus to impede drainage resulted in an accumulation of leukocytes to form a sterile pyometra similar to that observed in pseudopregnant animals (Broome et al., 1959). In our study, the viability of leukocytes in luminal flushings was high in oestrous gilts $(97 \pm 3 \%)$ but much lower in dioestrous animals $(55 \pm 4 \%)$, which could reflect a lower clearance rate in the progesterone-dominated uterus.

Immunological 'priming' of the uterus for pregnancy. The leukocytic response to mating may have a proactive role in preparing the maternal immune system for pregnancy. Several groups have reported that litter size in pigs can be increased by enhancing the immunological response to mating, by intrauterine infusion of either non-viable semen at the oestrus before mating (Murray et al., 1983; Murray and Grifo, 1986) or peripheral blood leukocytes at the time of insemination (Skjervold $e t$ al., 1979; Almlid, 1981). However, others have been unable to reproduce these effects (Blichtfeldt, 1984; Van der Lende et al., 1986; Giles et al., 1990). Interpretation of these studies is difficult because different stimuli were applied at different times, immune responses were not assessed, and litter size' $^{\prime}$ was determined at different times ranging from day 8-10 of gestation to 2 weeks post partum. Moreover, no attempt was made to control for exposure to seminal plasma, which is crucial if, as our data suggest, a factor(s) in seminal plasma initiates the response.

The mechanism by which seminal plasma elicits a leukocytic response has been characterized in mice (reviewed by Robertson et al., 1996). Robertson et al. (1996) hypothesized that seminal plasmainduced inhibition of potentially harmful cell-mediated immune activity against paternally inherited antigens of the conceptus facilitates implantation and placental development. Although their findings provide a conceptual framework for investigations of effects of seminal plasma in pigs, whether this state of anergy influences the outcome of pregnancy is unknown. The success of AI in the dairy industry in which a single ejaculate, the total volume of which varies from 2 to $10 \mathrm{ml}$, can be diluted to service hundreds of cows does not support a requirement for seminal-plasma mediated immunological priming in cattle. With respect to AI in pigs, any effect of seminal plasma in preventing uterine infection is met by the addition of antibiotics to semen extenders, but it is possible that variations in exposure to seminal plasma could contribute to differences in litter size. Owing to the relatively low concentrations of spermatozoa in boar semen, the proportion of seminal plasma in a dose of semen diluted for AI can range from $50 \%$ to less than $10 \%$. We suggest that subtle influences on uterine leukocytes as a result of exposure to seminal plasma very early in gestation are most likely to have discernible effects on pregnancy outcome when conditions are suboptimal (as has been reported in women undergoing IVF or gamete intrafallopian transfer (GIFT): Bellinge et al., 1986; Marconi et al., 1989), or in litter-bearing species such as pigs in which incremental increases in prolificacy can be realised.

\section{The Maternal Immune Response to Pregnancy}

\section{Uterine leukocyte populations in the non-pregnant pig}

Before puberty, neutrophils are the predominant immune cells in the pig uterus; $\mathrm{MHC}$ class $\mathrm{II}^{+}$ cells (macrophages and dendritic cells) and lymphocytes are also common (Bischof et al., 1994). In the cyclic animal, the most numerous leukocytes are lymphocytes, followed by macrophages and 
neutrophils. Lymphocytes are located in the stroma and the luminal epithelium, both between epithelial cells and in basal positions (Bischof et al., 1994). The most striking change in uterine leukocyte distribution during the cycle is the infiltration of large numbers of neutrophils at oestrus (Corner, 1921; Bischof et al., 1994). This event is probably mediated, directly or indirectly, by high concentrations of circulating oestrogens. Oestradiol has been shown to increase uterine blood flow (Ford and Christenson, 1979) and endometrial vascular permeability in pigs (Keys and King, 1988). Other stage-dependent changes in leukocyte populations are more debatable. King (1988) noted a modest, but statistically significant increase in the number of lymphocytes (identified morphologically) within the uterine epithelium from days 10 to 19 of the cycle. However, using lymphocyte surface markers (CD2, CD4 and CD8), Bischof et al. (1994) reported a marked reduction in the number of lymphocytes at midcycle (days 10-12) relative to earlier in the cycle (days 2-4) in both the epithelial and stromal compartments. Most lymphocytes in the pig uterus express the CD2 surface marker; $C D 2^{+}$lymphocytes were predominantly $\mathrm{CD} 8^{+}$, particularly in the epithelium, with fewer $\mathrm{CD}^{+}$cells (Bischof $e t$ al., 1994). It must be noted that reliance on surface markers (primarily $\mathrm{CD} 2, \mathrm{CD} 4, \mathrm{CD} 8$ ) may result in the failure to detect lymphocytes with the CD2-CD4-CD8- (triple negative) phenotype. In pigs, this phenotype is typical of $\gamma \delta$ T cells (Hirt et al., 1990), which are known to play important roles at mucosal surfaces.

\section{The effect of pregnancy on lymphocytes within the luminal epithelium}

Because intraepithelial lymphocytes, usually $\mathrm{T}$ cells, are believed to have special functions at other mucosal surfaces, it is possible that uterine intraepithelial lymphocytes play a role in pregnancy. King (1988) found that numbers of lymphocytes within the luminal epithelium at days $10,13,16$ and 19 of pregnancy were significantly lower than those at comparable stages of the oestrous cycle, and decreased as gestation progressed. Similarly, Bischof et al. (1995) reported that there were significantly fewer lymphocytes (CD2 ${ }^{+}$cells) within the epithelium on days 18-21 of gestation than on days 18-21 of the cycle. Trophoblast may mediate this effect. Bischof et al. (1995) noted that at days $28-30$ and $45-80$ of gestation, intraepithelial lymphocytes were completely absent except in areolar regions, where glands open into the uterine lumen. At these sites, there is no contact between trophoblast and maternal tissues. Although placental structure is somewhat different in ruminants, similar findings have been reported. In cattle and sheep, chorionic binucleate cells migrate across the placental interface and fuse with uterine epithelial cells or other binucleate cells (reviewed by King, 1993). These multinucleate complexes subsequently spread to produce an extensive syncytium on the maternal side. As in pigs, intraepithelial lymphocytes decrease in number during early pregnancy in sheep (Staples et al., 1983; Lee et al., 1992) and cattle (Van der Wielen and King, 1984). Analogous to the situation at areolae in the pig placenta, intraepithelial lymphocytes are completely absent from syncytial regions in cattle (Van der Wielen and King, 1984) and sheep (Staples et al., 1983; Gogolin-Ewens et al., 1989).

Because most of the research in pigs has concentrated on the first third of pregnancy, little is known about uterine leukocyte distribution later in gestation. In sheep (Lee et al., 1992) and possibly other ruminant species (Kellas, 1961; Lee et al., 1995), the decrease in intraepithelial lymphocytes during early pregnancy is overshadowed by a marked increase in the frequency of granulated lymphocytes within the luminal epithelium during mid- to late gestation. These lymphocytes have been found to be an unusual subset of $\gamma \delta \mathrm{T}$ cells (Meeusen $e t$ al., 1993) that increase in size, number and apparent activation during mid- to late gestation (Gogolin-Ewens et al., 1989; Lee et al., 1992; Meeusen et al., 1993). Using a model in which pregnancy was surgically confined to one uterine horn, Liu et al. (1997) showed that in the pregnant horn, a higher proportion of these cells expressed selected activation markers, suggesting that a conceptus-derived molecule induced the activation.

Because pigs are similar to ruminants in that $\gamma \delta \mathrm{T}$ cells constitute a major circulating T-cell subpopulation (Hirt et al., 1990; Hein and Mackay, 1991), a possible role for uterine $\gamma \delta \mathrm{T}$ cells in pregnancy in pigs warrants further investigation. However, the lack of antibodies to detect the pig $\gamma \delta$ T-cell receptor has hindered investigations. An antibody recognizing a determinant of the $\delta$ chain of the pig $\gamma \delta$ T-cell receptor recently became available (VMRD Inc., Pullman, WA). In preliminary 
Table 2. Distribution of leukocytes in epithelial and stromal compartments of pig endometrium during early pregnancy (means \pm SEM) ${ }^{\circ}$

\begin{tabular}{clcc}
\hline $\begin{array}{c}\text { Stage of gestation } \\
\text { (day) }\end{array}$ & Position & $\begin{array}{c}\text { Epithelium } \\
\text { (cells mm } \text { m }^{-1}\end{array}$ & $\begin{array}{c}\text { Stroma } \\
\text { (cells mm } \text { m }^{-2} \text { ) }\end{array}$ \\
\hline $15-17$ & at & $0.6 \pm 0.2$ & $411 \pm 77^{*}$ \\
& between & $0.5 \pm 0.04$ & $127 \pm 27$ \\
$18-19$ & at & $0.8 \pm 0.4$ & $272 \pm 24^{*}$ \\
& between & $1.5 \pm 0.2$ & $79 \pm 1.8$ \\
$21-22$ & at & $0.2 \pm 0.1$ & $290 \pm 37^{*}$ \\
& between & $0.1 \pm 0.1$ & $142 \pm 24$ \\
$25-27$ & at & $0.4 \pm 0.1$ & $295 \pm 17^{*}$ \\
& between & 0 & $135 \pm 42$ \\
\hline
\end{tabular}

-Tissue was collected from the mesometrial aspect of the uterus from sites in contact with and equidistant from attached conceptuses (designated 'at' and 'between' attachment sites, respectively). Leukocytes were localized by indirect immunohistochemistry using a pan leukocyte marker (CD44) as the primary antibody. $\mathrm{CO} 44^{*}$ cells were quantified in luminal epithelium and in the associated area of endometrial stroma to a depth of approximately $150 \mu \mathrm{m}$ using image analysis software (Mocha Verson 1.2, Jandel Scientific, San Rafael, CA).

'Significantly greater than in tissue collected between' attachment sites at the same stage of gestation $(P<0.05)$.

investigations using enzymatically dispersed, gradient-purified endometrial cells from day 21-22 of gestation, we have found that this anti- $\delta$ chain antibody binds to a subpopulation of uterine leukocytes (about $7 \%$ ) and to a somewhat higher proportion of peripheral blood mononuclear cells (about $23 \%$ ). We are currently examining sections of uteri of pregnant pigs using this antibody.

\section{Conceptus-associated leukocytes in the endometrial stroma during early pregnancy}

It is generally necessary to use surface markers to identify accurately leukocytes in the heterogeneous mixture of cells making up the endometrial stroma. Bischof et al. (1995) detected stromal lymphocytes in pig endometrial tissue by their expression of CD2 (T cells and NK cells), and further characterized them by their expression of CD4 and CD8 antigens. They noted a significant increase in numbers of stromal lymphocytes from days 10-14 to 18-21 of gestation. At days 28-30, lymphocytes were frequently seen closely packed within blood vessels immediately beneath the luminal epithelium, around glands and blood vessels, and also scattered through the stroma, occasionally in large groups. MHC class $\mathrm{II}^{+}$macrophages and dendritic cells were also seen in the stroma. By days 45-80, macrophages and dendritic cells were the predominant stromal leukocytes.

We have taken a somewhat different approach to sample selection for histology. We collected tissues from the mesometrial aspect of the pregnant uterus at sites immediately adjacent to, and equidistant from conceptuses (designated 'at' and 'between' attachment sites, respectively) during early pregnancy (days 15-17, 18-19, 21-22 and 25-27; Swatman et al., 1996). By comparing these regions with respect to the number of leukocytes in epithelial and stromal compartments, we hoped to distinguish between local influences of conceptuses and the systemic effects of pregnancy. Leukocytes were identified using the CD44 pan leukocyte marker. Proximity to the conceptus had a marked effect on stromal leukocyte distribution, in that leukocytes were 2.0-3.5 times more numerous in regions in direct contact with conceptuses than in regions between attachment sites at all stages $(P=0.0001$; Table 2). Numbers of intraepithelial leukocytes were low and were not influenced by proximity to attachment sites $(P=0.55)$.

Chemotactic factors secreted by the pig conceptus. The mechanism by which the pig conceptus attracts leukocytes to the endometrial stroma is unknown. Although leukocytes are passively transported by the vascular system, their entry into tissues involves a coordinated series of events, namely activation of leukocyte integrins, adhesion to the vascular endothelium, and migration 
(Dunon et al., 1996). Expression of selected integrin subunits on luminal epithelium and trophoblast has been investigated during early pregnancy in pigs with respect to the timing of blastocyst attachment and regulation by steroid hormones (Bowen et al., 1996). In sheep, the presence of a conceptus is associated with increased expression of L-selectin by $\gamma \delta \mathrm{T}$ cells within the luminal epithelium (Liu et al., 1997). However, no information has been reported on the expression of these molecules in the subepithelial stroma in either species.

Through their induction of subset-specific adhesion of leukocytes to endothelial cells, cytokines are believed to be key players in leukocyte entry into tissues (Tanaka et al., 1993; Dunon et al., 1996). CSF-1 expression by pig trophectoderm has been reported, but the fact that expression was low up to day 20 (Tuo et al., 1995) makes it unlikely to mediate the shift in leukocyte distribution, which has already occurred by days 15-17. The pig conceptus secretes two types of interferons (IFNs) during the attachment period: IFN $\gamma$ and spl-IFN, a novel type I IFN (Lefèvre et al., 1990; 1993). Although the timing and site of their synthesis has been well documented (Cross and Roberts, 1989; Mirando et al., 1990; LaBonnardière et al., 1991), their role in pregnancy is still unknown. IFNs are known to modulate leukocyte function, and IFN $\gamma$ in particular is a potent activator of NK cells (Reiter, 1993). It is therefore possible that one or both of these conceptus-derived IFNs is involved in the attraction of leukocytes to attachment sites.

Although not normally considered a chemoattractant molecule for leukocytes, the fact that oestrogen is secreted by the pig trophoblast around the time of attachment (reviewed by Geisert $e t$ al., 1990) suggests that it may participate in the attraction of lymphocytes to attachment sites. Oestrogen may indirectly promote lymphocyte accumulation through its effects on endometrial vasculature. Blood flow to uterine segments in contact with conceptuses is higher than that in segments not in contact (Ford et al., 1982). Initial contact between the conceptus and the endometrium (Dantzer, 1984), and, after a delay of 1-2 days, the first increase in capillary density (Dantzer and Leiser, 1994) occur at the embryonic disc regions which have the highest rates of oestrogen synthesis (Bate and King, 1988). Localized alterations in subepithelial capillaries resembling those occurring in early pregnancy can be simulated by surgical insertion of oestrogensecreting Silastic beads into the uterine lumen (Keys and King, 1992). It is also possible that conceptus-derived oestrogen plays a more direct role in lymphocyte homing to the endometrium. Oestrogen receptors are expressed on vascular endothelial cells of several species (Farhat et al., 1996) and on specialized lymphocytes that localize to attachment sites in the mouse uterus (Van den Heuvel et al., 1996).

\section{Pregnancy-associated NK cells in the pig uterus}

Evidence from functional studies suggests that NK-like cells are present in the pig endometrium (Croy et al., 1988; Yu et al., 1993). Lysis of conventional NK target cells by dispersed endometrial cells was high at days 10 and 20 of pregnancy and undetectable in cyclic animals (Yu et al., 1993). The fact that this increase in lytic activity was not detected at comparable stages of oestrogen-induced pseudopregnancy suggests that it was a response to the presence of conceptuses rather than the endocrine milieu of pregnancy (Yu et al., 1993). Because NK cell-specific markers have not been widely available in pigs, the distribution of uterine NK cells relative to the maternal-fetal interface is not currently known. Lymphocytes in pig peripheral blood exhibiting NK-cell-like activity have the phenotype CD2 ${ }^{C D} 4-C D 8^{\text {dim }}$ (Yang and Parkhouse, 1996), such that the only feature that distinguishes them from subsets of both $\alpha \beta$ and $\gamma \delta \mathrm{T}$ cells is their lack of CD3 expression. Functionally, the distinction between NK cells and $\gamma \delta$ T cells in pigs is somewhat unclear. Cells with the precise phenotype and activity of NK cells as defined in mice may not exist in livestock species (reviewed by Engelhardt and King, 1996). However, typical NK functions may be carried out by other lymphocyte subsets. In cattle, for instance, $\gamma \delta \mathrm{T}$ cells exhibit non MHC-restricted cytolytic activity against NK-sensitive targets (Brown et al., 1994).

Investigations into the identity of lytic cells from early pregnant pig endometrium have continued using the monoclonal antibody G7 (generously provided by Y. B. Kim, University of North Chicago). This antibody was raised in mice immunized with a pig peripheral blood fraction 
Mating

Seminal plasma factors

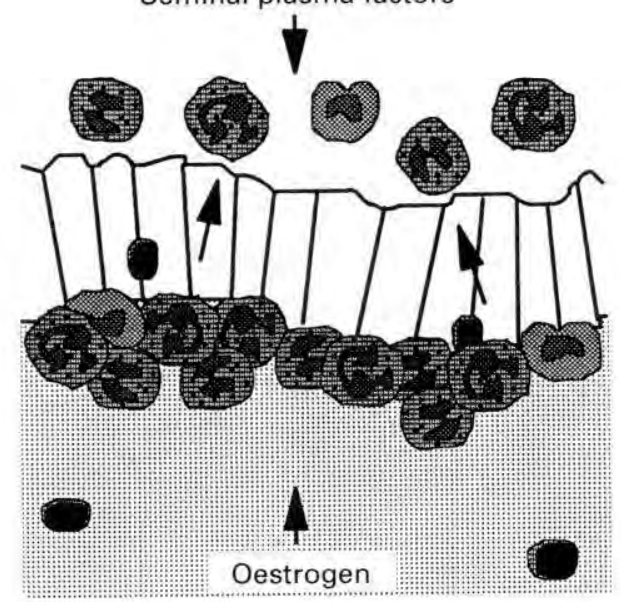

Response

- Influx of inflammatory cells into uterus

- primarily neutrophils

\section{Stimulus}

- Oestrogen and seminal plasma factors
Early pregnancy

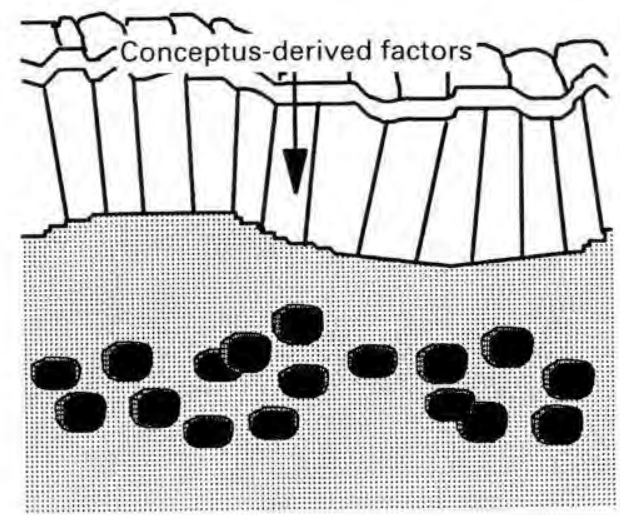

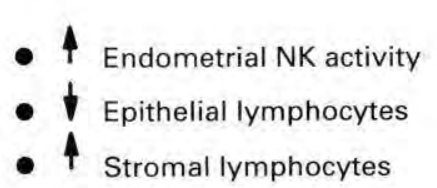

- Conceptus-derived factors

- Oestrogen? IFN?

Fig. 5. Summary of the responses of pig uterine immune cells to mating and pregnancy. The influx of inflammatory leukocytes at mating is largely hormonally regulated, but is amplified by factors in seminal plasma. In addition to preventing infection, the leukocytic response to mating may have subtle effects on the maternal immune system that enhance implantation or embryo survival. Marked changes occur in the distribution of uterine immune cells during early pregnancy (days 15-27). The factors mediating these responses have not yet been identified, but conceptus-derived oestrogen and interferon are likely candidates. These conceptus-associated leukocytes may be mediators of communication between conceptuses and other leukocytes, non-immune cells or vascular elements within the uterus during pregnancy.

enriched for NK cells (Dato et al., 1992). In addition to NK cells, G7 reacts with granulocytes and macrophages. Using flow cytometry, we have determined the proportion of uterine leukocytes $\left(\mathrm{CD} 44^{+}\right.$cells) binding to the G7 antibody in dispersed, gradient-purified endometrial cells obtained both at and between attachment sites during early pregnancy (Engelhardt et al., 1996; Engelhardt and King, 1996). However, after accounting for granulocyte and macrophage reactivity, the frequency of $\mathrm{G7}^{+}$lymphocytes at versus between attachment sites was found to be similar.

It is currently not known whether the $\mathrm{G7}^{+}$uterine lymphocytes are the same population mediating the pregnancy-associated lytic activity. The cell surface antigen recognized by G7 has been shown to be the pig homologue of a form of the low-affinity Fc receptor for IgG (Fc $\gamma$ RIIIA $\alpha$ ), designated CD16 (Halloran et al., 1994). In humans, while circulating NK cells are typically CD16 , the subset populating the pregnant uterus are CD16- (King et al., 1996). Because uterine lymphocytes in the pig placenta are never in contact with trophoblast, regulation of triggering molecules such as CD16 on uterine NK cells may be quite different from that in humans. Pig uterine NK cells may all be $\mathrm{CD}_{16} 6^{+}$, as in the circulation, or positive and negative subpopulations may be present, with the $\mathrm{CD}^{-} 6^{-}$subset being activated by pregnancy. Efforts are currently underway to assess the lytic activity 
of isolated $\mathrm{G7}^{+}$uterine lymphocytes, and to localize putative NK cells in tissue sections using G7 along with other surface markers.

Speculations on the role of uterine NK cells in pregnancy in pigs. The presence of potentially lytic cells in the endometrium of the pregnant uterus raises the question of whether trophoblast cells are susceptible to lysis by NK cells. Reports in humans (King et al., 1989; King and Loke, 1990) and rodents (Zuckerman and Head, 1988; Drake and Head, 1989) that NK cells were unable to lyse trophoblast unless first activated by IL-2 led to the hypothesis that preventing IL-2 activation of NK cells might be involved in the protection of trophoblast. In pigs, however, endometrial cells obtained at early post-attachment times (days 17-20) recognize and kill both conventional NK target cells and trophoblast cells without prior activation of IL-2 (Croy et al., 1994; Yu et al., 1994). Because pig uterine lymphocytes are not likely to encounter trophoblast directly in vivo, the evolution of mechanisms to block IL-2 activation of uterine NK cells in this species may not have been necessary.

Given the architecture of the pig placenta, the cytokine-secreting abilities of uterine NK cells are likely to be more important than lytic functions that require cell to cell contact. In response to a conceptus-derived signal, for example IFN, uterine NK cells may communicate with leukocytes or non-immune cells within the uterus via secretion of cytokines, effecting alterations in levels of activity. The nature of these interactions and the identity of the target cells are undefined. Recent observations in three strains of mice genetically lacking NK cells have provided new insights on the possible role of uterine NK cells (Croy et al., 1997b; Guimond et al., 1997). In these mice, placentae of viable conceptuses were less than half of normal size at mid-gestation, and pathological changes in placental vasculature were evident (Guimond, 1997). Because placental size and development in four strains of mice lacking T cells are normal (Croy and Kiso, 1993; Croy et al., 1997c; Guimond, 1997), these effects were attributed to the lack of uterine NK cells. This was supported by the findings that placental vasculature and size were partially restored by the adoptive transfer of bone marrow from scid mice $\left(\mathrm{T}^{-} \mathrm{B}^{-} \mathrm{NK}^{+}\right)$into TgE26 females ( ${ }^{-} \mathrm{B}^{+} \mathrm{NK}^{-}$; Guimond, 1997). These findings have led to the hypothesis that uterine NK cells promote trophoblast growth or viability indirectly by regulating blood flow to the implantation site. This notion is also supported by evidence that in the uterus of normal mice, uterine NK cells are the major source of nitric oxide synthase, an enzyme responsible for the release of the vasoactive compound nitric oxide (Hunt et al., 1997). In pigs, as early as day 15 when interdigitating microvilli form between maternal and fetal layers, there is a remarkable increase in capillary density and size in the maternal subepithelial bed on the mesometrial side (Dantzer and Leiser, 1994). The fact that extensive angiogenesis occurs during the period of high NK-like activity in the pig suggests that secretory products of NK cells or other leukocytes might be involved in the development or regulation of endometrial vasculature in this species.

\section{Conclusion}

Clearly, uterine leukocytes in sows do respond to the immunological challenges of both mating and pregnancy (summarized in Fig. 5). The leukocytic response to mating is partially under endocrine control, but is amplified by exposure of the uterine mucosa to as yet unidentified factors in the seminal plasma. In addition to preventing microbial infection, we propose that the mating response exerts subtle influences on uterine leukocytes that may enhance reproductive performance in litterbearing species such as pigs. Whether exposure to seminal plasma in pigs produces a state of hyporesponsiveness to paternal antigens comparable with that described in mice by Robertson et al. (1996), and whether this state affects pregnancy outcome remains to be determined. These findings may have important implications for the AI industry, in that variations in the proportion of seminal plasma in semen prepared for AI may contribute to between and within boar variations in litter size.

The first month of pregnancy in pigs is interesting both immunologically, because intimate contact between maternal and fetal tissues is established, and economically, because a relatively large proportion of each litter is lost during this time. The accumulation of lymphocytes in the endometrial 
stroma at sites of conceptus attachment, together with the pregnancy-specific increase in activity of NK cells isolated from the endometrium indicate not only that the maternal immune system is aware of the genetically disparate conceptus, but also that the conceptus seems to be directing the activities of uterine leukocytes to its own advantage. Characterizing the pregnancy-associated lymphocytes, particularly with respect to whether the NK-like lymphocytes are the ones that localize to sites of conceptus attachment, and identifying the conceptus-derived factors that attract or activate them are areas of ongoing research. The role of these uterine leukocytes in pregnancy is still open to speculation. We propose that successful pregnancy requires a dialogue between the conceptus and leukocyte and non-leukocyte populations within the endometrium via soluble factors, and that interfering with this signalling may increase early pregnancy losses. Understanding the immunological events during this critical period of the establishment of maternal-fetal contact would allow the development of strategies to increase embryo survival, through either direct immunological interventions or the modification of husbandry practices shown to affect maternal-fetal signalling.

\section{References}

Abbas AK, Lichtman AH and Pober JS (1994) Cellular and Molecular Immunology (2nd Edn) WB Saunders Company, Philadelphia, PA

Alexander NJ and Anderson DJ (1987) Immunology of semen Fertility and Sterility 47 192-205

Almlid T (1981) Does enhanced antigenicity of semen increase the litter size in pigs? Zeitschrift für Tierzüchtung und Züchtungsbiologie 98 1-10

Bate LA and King GJ (1988) Production of oestrone and oestradiol-17 $\beta$ by different regions of the filamentous pig blastocyst Journal of Reproduction and Fertility 84 163-169

Bellinge BS, Copeland CM, Thomas TD, Mazzucchelli RE, O'Neil G and Cohen MJ (1986) The influence of patient insemination of the implantation rate in an in vitro fertilization and embryo transfer program Fertility and Sterility 46 2523-2526

Binns RM (1982) Organisation of the lymphoreticular system and lymphocyte markers in the pig Veterinary Immunology and Immunopathology 3 95-146

Bischof RJ, Brandon MR and Lee C-S (1994) Studies on the distribution of immune cells in the uteri of prepubertal and cycling gilts Journal of Reproductive. Immunology $\mathbf{2 6}$ 111-129

Bischof RJ, Brandon MR and Lee C-S (1995) Cellular immune response in the pig uterus during pregnancy Journal of Reproductive Immunology 29 161-178

Black WG, Simon J, McNutt SH and Casida LE (1953) Investigations on the physiological basis for the differential response of estrous and pseudopregnant rabbit uteri to induced infection American Journal of Veterinary Research 14 318-323

Blichtfeldt T (1984) Effect of addition of antigen, adjuvant or mitogen to semen on embryonic survival in artificially inseminated gilts Zeitschrift für Tierzüchtung und Züchtungsbiologie 101 298-304

Bowen JA, Bazer FW and Burghardt RC (1996) Spatial and temporal analyses of integrin and muc-1 expression in porcine uterine epithelium and trophectoderm in vivo Biology of Reproduction 55 1098-1106

Broome AWJ, Lamming GE and Smith W (1959) Studies on the relationship between ovarian hormones and uterine infection IV: the role of the granulocyte system in uterine defence Journal of Endocrinology 19 274-281
Brown WC, Davis WC, Choe SH, Dobbelaere DAE and Splitter GA (1994) Functional and phenotypic characterization of $W C 1^{+} \gamma / \delta \mathrm{T}$ cell isolated from Babesia bovis-stimulated T cell lines Cellular Immunology 153 9-27

Burger JF (1952) Sex physiology of pigs Onderstepoort Journal of Veterinary Research 26 (Supplement) 2

Corner GW (1921) Cyclic changes in the ovaries and uterus of the sow, and their relation to the mechanism of implantation Contributions to Embryology 13 117-146

Cross JC and Roberts RM (1989) Porcine conceptuses secrete an interferon during the preattachment period of early pregnancy Biology of Reproduction 40 1109-1118

Croy BA and Kiso Y (1993) Granulated metrial cells: a natural killer cell subset of the pregnant murine uterus Microscopy Research and Technique 25 189-200

Croy BA, Waterfield A, Wood W and King GJ (1988) Normal murine and porcine embryos recruit NK cells to the uterus Cellular Immunology 115 471-480

Croy BA, Yu Z-M and King GJ (1994) A review of the natural killer cell lineage of the mouse and of the pig Journal of Animal Science 72 (Supplement 2) 9-15

Croy BA, Luross JA, Guimond MJ and Hunt JS (1996) Uterine natural killer cells: insights into lineage relationships and functions from studies of pregnancies in mutant and transgenic mice Natural Immunity 15 22-33

Croy BA, Whitelaw PF and Engelhardt H (1997a) The influences of immune cells on the success of pregnancy. In The Endocrinology of Pregnancy Ed. F W Bazer. Humana Press Inc., Totowa N.J. (in press)

Croy BA, Ashkar AA, Foster RA, DiSanto JP, Magram J, Carson D, Gendler SJ, Grusky MJ, Wagner N, Muller W and Guimond MJ (1997b) Further evidence from histological assessment of implantation sites from gene-ablated mice that natural killer cells have important functions in the uterus during pregnancy Journal of Reproductive Immunology (in press)

Croy BA, Guimond M-J, Luross J, Hahnel A, Wang B and Van den Heuvel M (1997c) Uterine natural killer cells do not require interleukin-2 for their differentiation or maturation American Journal of Reproductive Immunology 37 463-470

Dantzer V (1984) Scanning electron microscopy of exposed surfaces of the porcine placenta Acta Anatomica 118 96-106 Dantzer V and Leiser R (1994) Initial vascularisation in the pig placenta: I. Demonstration of nonglandular areas by 
histology and corrosion casts The Anatomical Record 238 177-190

Dato ME, Wierda WG and Kim YB (1992) A triggering structure recognized by G7 monoclonal antibody on porcine lymphocytes and granulocytes Cellular Immunology 140 468-477

Drake BL and Head JR (1989) Murine trophoblast can be killed by lymphokine-activated killer cells Journal of Immunology 143 9-14

du Mesnil du Buisson F and Dauzier L (1955) La remontée des spermatozoides du verrat dans le tractus génital de la truie en oestrus Comptes Rendus des Société Biologie (Paris) 149 76-79

Dunon D, Piali L and Imhof BA (1996) To stick or not to stick: the new leukocyte homing paradigm Current Opinion in Cell Biology 8 714-723

Engelhardt H and King GJ (1996) Uterine natural killer cells in species with epitheliochorial placentation Natural Immunity $1553-69$

Engelhardt H, Small MR and King GJ (1996) Exposure of pigs to seminal plasma at estrus recruits leukocytes to the uterine epithelium Biology of Reproduction 54 (Supplement 1) Abstract 476

Farhat MY, Lavigne MC and Ramwell PW (1996) The vascular protective effects of estrogen FASEB Journal $10615-624$

Ford SP and Christenson RK (1979) Blood flow to uteri of sows during the estrous cycle and early pregnancy: local effect of the conceptus on the uterine blood supply Biology of Reproduction 21 617-624

Ford SP, Reynolds LP and Magness RR (1982) Blood flow to the uterine and ovarian vascular beds of gilts during the estrous cycle or early pregnancy Biology of Reproduction 27 878-885

Geisert RD, Zavy MT, Moffatt RJ, Blair RM and Yellin T (1990) Embryonic steroids and the establishment of pregnancy in pigs Journal of Reproduction and Fertility Supplement 40 293-305

Giles JR, Thompson LH, Arkins S, Camacho T and Eichen PA (1990) Effects of uterine infusion of non-viable semen, seminal plasma or egg albumin prior to breeding on the reproductive efficiency of gilts or sows Canadian Journal of Animal Science 70 129-133

Gogolin-Ewens KJ, Lee CS, Mercer WR and Brandon MR (1989) Site-directed differences in the immune response to the fetus Immunology 66 312-317

Guimond M-J (1997) Evaluations of functions of uterine natural killer cells during pregnancy in mice $\mathrm{PhD}$ Thesis, University of Guelph

Guimond M-J, Luross JA, Wang B, Terhorst C, Danial S and Croy BA (1997) Absence of natural killer cells during murine pregnancy in associated with reproductive compromise in TgE26 mice Biology of Reproduction 56 169-179

Guy-Grand D, Cerf-Bensussan N, Malissen B, Malassis-Seris ML, Briottet C and Vassalli P (1991) Two gut intraepithelial CD8 ${ }^{+}$ lymphocyte populations with different $\mathrm{T}$ cell receptors: a role for the gut epithelium in T cell differentiation Journal of Experimental Medicine 173 471-481

Hadjisavas M Laurenz JC and Bazer FW (1994) Seminal plasma (SPL): a potential mediator of inflammation in the uterus following mating in the pig Biology of Reproduction $\mathbf{5 0}$ (Supplement 1) Abstract 76

Halloran PJ, Sweeney SE, Strohmeier CM and Kim YB (1994) Molecular cloning and identification of the porcine cytolytic trigger molecule G7 as a FcrRII $\alpha$ (CD16) homologue Journal of Immunology 153 2631-2641
Head JR (1996) Uterine natural killer cells during pregnancy in rodents Natural Immunity 15 7-21

Hein WR and Mackay CR (1991) Prominence of gamma-delta T cells in the ruminant immune system Immunology Today 12 30-34

Hirt W, Saalmüller A and Reddehase MJ (1990) Distinct $\gamma / \delta$ T cell receptors define two subsets of circulating porcine CD2-CD4-CD8- T lymphocytes European Journal of Immunology 20 265-269

Hunt JS, Miller L, Vassmer D and Croy BA (1997) Expression of the inducible nitric oxide synthase gene in mouse uterine leukocytes and potential relationships with uterine function during pregnancy Biology of Reproduction (in press)

Kellas LM (1961) An intra-epithelial granular cell in the uterine epithelium of some ruminant species during the pregnancy cycle Acta Anatomica 44 109-130

Keys JL and King GJ (1988) Morphological evidence for increased uterine vascular permeability at the time of embryonic attachment in the pig Biology of Reproduction 39 473-487

Keys JL and King GJ (1990) Microscopic examination of porcine conceptus-maternal interface between days 10 and 19 of pregnancy American Journal of Anatomy 188 221-238

Keys JL and King GJ (1992) Effects of topical and systemic estrogen on morphology of porcine uterine luminal epithelia Biology of Reproduction 46 1165-1175

King A and Loke YW (1990) Human trophoblast and JEG choriocarcinoma cells are sensitive to lysis by IL-2stimulated decidual NK cells Cellular Immunology 127 230-237

King A, Birkby A and Loke YW (1989) Early human decidual cells exhibit NK activity against the K562 cell line but not first trimester trophoblast Cellular Immunology 118 337-344

King A, Burrows T and Loke YW (1996) Human uterine natural killer cells Natural Immunity 15 41-52

King GJ (1988) Reduction in uterine intra-epithelial lymphocytes during early gestation in pigs Journal of Reproductive Immunology 14 41-46

King GJ (1993) Comparative placentation in ungulates Journal of Experimental Zoology 266 588-602

LaBonnardière C, Martinat-Botté F, Terqui M, Lefèvre F, Zouari K, Martal J and Bazer FW (1991) Production of two species of interferon by Large White and Meishan pig conceptuses during the peri-attachment period Journal of Reproduction and Fertility $91469-478$

Lee CS, Meeusen E, Gogolin-Ewens K and Brandon MR (1992) Quantitative and qualitative changes in the intraepithelial lymphocyte population in the uterus of nonpregnant and pregnant sheep American Journal of Reproductive Immunology 28 90-96

Lee CS, Wooding FPB and Morgan G (1995) Quantitative analysis of large granular lymphocyte distribution and maternofetal interactions in the synepitheliochorial placenta of the deer Journal of Anatomy 187 445-460

Lefèvre F and Boulay V (1993) A novel and atypical type one interferon gene expressed by trophoblast during early pregnancy Journal of Biological Chemistry 268 19 760-19 768

Lefèvre F, Martinat-Botté F, Guillomot M, Zouari K, Charley B and La Bonnardière C (1990) Interferon-gamma gene and protein are spontaneously expressed by the trophectoderm early in gestation European Journal of Immunology 20 2485-2490

Liu WJ, Gottshall SL and Hansen PJ (1997) Increased expression of cell surface markers on endometrial $\gamma \delta$ T-cell receptor ${ }^{+}$ intraepithelial lymphocytes induced by the local presence 
of the sheep conceptus American Journal of Reproductive Immunology 37 1-7

Lovell JE and Getty R (1968) Fate of semen in the uterus of the sow: histologic study of endometrium during the 27 hours after natural service American Journal of Veterinary Research 29 609-624

McDermott MR and Bienenstock J (1979) Evidence for a common mucosal immunologic system: I. migration of B immunoblasts into intestinal, respiratory, and genital tissues Journal of Immunology 122 1892-1898

McDermott MR, Clark DA and Bienenstock J (1980) Evidence for a common mucosal immunologic system: II. influence of the estrous cycle on B immunoblast migration into genital and intestinal tissues Journal of Immunology 124 2536-2539

Marconi G, Auge L, Oses R, Qunitana R Raffo F and Young E (1989) Does sexual intercourse improve pregnancy rates in gamete intrafallopian tube transfer? Fertility and Sterility 51 357-359

Meeusen E, Fox A, Brandon M and Lee CS (1993) Activation of uterine intraepithelial gamma-delta $\mathrm{T}$ cell receptorpositive lymphocytes during pregnancy European Journal of Immunology 23 1112-1117

Mirando MA, Harney JP, Beers S, Pontzer CH, Torres BA, Johnson HM and Bazer FW (1990) Onset of secretion of proteins with antiviral activity by pig conceptuses Journal of Reproduction and Fertility 88 197-203

Moebius U, Kober G, Griscelli AL, Hercend T and Meuer SC (1991) Expression of different CD8 isoforms on distinct human lymphocyte subpopulations European Journal of Immunology 21 1793-1800

Murray FA and Grifo APJ (1986) Intrauterine infusion of killer semen to increased litter size in gilts Journal of Animal Science 62 187-190

Murray FA, Grifo AP and Parker CF (1983) Increased litter size in gilts by intrauterine infusion of seminal plasma and sperm antigens before breeding Journal of Animal Science 56 895-900

Pescovitz MD, Lunney JK and Sachs DH (1985) Murine antiswine T4 and T8 monoclonal antibodies: distribution and effects on proliferative and cytotoxic T cells Journal of Immunology 134 37-44

Pescovitz MD, Lowman MA and Sachs DH (1988) Expression of T-cell associated antigens by porcine natural killer cells Immunology 65 267-271

Polge C, Rowson LEA and Chang MC (1966) The effect of reducing the number of embryos during early stages of gestation on the maintenance of pregnancy in the pig Journal of Reproduction and Fertility 12 395-397

Reiter ZVI (1993) Interferon - a major regulator of natural killer cell-mediated cytotoxicity Journal of Interferon Research 13 247-257

Robertson SA, Mau VJ, Hudson SN and Trellen KP (1997) Cytokine-leukocyte networks and the establishment of pregnancy American Journal of Reproductive Immunology 37 $438-442$

Rowson LEA, Lamming GE and Fry RM (1953) The relationship between ovarian hormones and uterine infection The Veterinary Record 65 335-340

Saalmüller A, Reddehase MJ, Bühring H-J, Jonjic S and Koszinowski UH (1987) Simultaneous expression of CD4 and CD8 antigens by a substantial proportion of resting porcine T lymphocytes European Journal of Immunology 17 1297-1301

Saalmüller A, Hirt W and Reddehase MJ (1990) Porcine $\gamma / \delta$ T lymphocyte subsets differing in their propensity to home to lymphoid tissue European Journal of Immunology 20 2343-2346
Scofield AM, Clegg FC and Lamming GE (1974) Embryonic mortality and uterine infection in the pig Journal of Reproduction and Fertility 36 353-361

Skjervold H, Amlid T, Onstad O and Fossum K (1979) Evidence of immunological influence on the number of live embryos in pigs Zeitschrift für Tierzüchtung und Züchtungsbiologie 96 235-236

Staples LD, Heap RB, Wodding FBP and King GJ (1983) Migration of leukocytes into the uterus after acute removal of ovarian progesterone duing early pregnancy in the sheep Placenta 4 339-350

Swatman J, King GJ and Engelhardt H (1996) Leukocyte distribution in the pig uterus relative to sites of conceptus attachment during early pregnancy Biology of Reproduction 54 (Supplement 1) Abstract 475

Tanaka Y, Adams DH and Shaw S (1993) Proteoglycans on endothelial cells present adhesion-inducing cytokines to leukocytes Immunology Today 14 111-115

Thaler CJ (1989) Immunological role for seminal plasma in insemination and pregnancy American Journal of Reproductive Immunology 21 147-150

Tuo W, Harney JP and Bazer FW (1995) Colony-stimulating factor- 1 in conceptus and uterine tissues in pigs Biology of Reproduction 53 133-142

Van den Heuvel M, McBey B-A, Hahnel AC and Croy BA (1996) An analysis of the uterine lymphocyte-derived hybridoma cell line GWM 1-2 for expression of receptors for estrogen, progesterone and interleukin 2 Journal of Reproductive Immunology 31 37-50

Van der Lende T, Donker R and Hazeleger W (1986) Embryonic survival in the pig after insemination with antigenenriched semen Theriogenology 26 391-396

Van der Wielen AL and King GJ (1984) Intraepithelial lymphocytes in the bovine uterus during the oestrous cycle and early gestation Journal of Reproduction and Fertility $70457-462$

Viring S and Einarsson S (1981) Sperm distribution within the genital tract of naturally inseminated gilts Nordisk Veterinär Medicin 33 145-149

Wira CR, Hyde E, Sandoe CP, Sullivan D and Spencer S (1980) Cellular aspects of the rat uterine $\mathrm{IgA}$ response to estradiol and progesterone Journal of Steroid Biochemistry 12 451-459

Wira CR, Sullivan DA and Sandoe CP (1983) Epithelial cell involvement in the estrogen stimulated accumulation of $\operatorname{IgA}$ in the rat uterus Journal of Steroid Biochemistry 19 $469-474$

Yang H and Parkhouse RME (1996) Phenotypic classification of porcine lymphocyte subpopulations in blood and lymphoid tissues Immunology 89 76-83

Yu Z, Croy BA, Chapeau C and King GJ (1993) Elevated endometrial natural killer cell activity during early porcine pregnancy is conceptus-mediated Journal of Reproduction and Fertility 24 153-164

Yu Z, Croy BA and King GJ (1994) Lysis of porcine trophoblast cells by endometrial natural killer-like effector cells in vitro does not require interleukin-2 Biology of Reproduction 51 $1279-1284$

Zuckerman FA and Head JR (1988) Murine trophoblast resists cell-mediated lysis. II. Resistance to natural cell-mediated cytotoxicity Cellular Immunology 116 274-286

Zuckerman FA, Binns RM, Husmann R, Yang H, Carr MM, Kim YB, Davis WC, Misfeldt M and Lunney JK (1994) Analyses of monoclonal antibodies reactive with porcine CD44 and CD45 Veterinary Immunology and Immunopathology 43 293-305 